\title{
The 18C's model for a successful long-term outsourcing arrangement ${ }^{\text {t }}$
}

\author{
Alessio Ishizaka*, Rebecca Blakiston \\ University of Portsmouth, Portsmouth Business School, Richmond Building, Portland Street, Portsmouth P01 3DE, United Kingdom
}

\section{A R T I C L E I N F O}

Article history:

Received 13 April 2010

Received in revised form 24 October 2011

Accepted 26 February 2012

Available online $\mathrm{xxxx}$

\section{Keywords:}

Outsourcing

Long-term relationships

Facility management

\begin{abstract}
A B S T R A C T
The purpose of this paper is to identify the factors that contribute to a successful long-term outsourcing arrangement, particularly in the facilities management area. Organisations expect to achieve many benefits from outsourcing, despite the fact that there are significant risks associated with unsuccessful outsourcing. The paper analyses a successful multiple activity outsourcing case study. Six managers and team leaders, who have initiated and managed the sixteen outsourced activities during an eight year period, were interviewed. In order to complement and confirm the interviews, the observation of four monthly performance review meetings was conducted. Eighteen key success factors for a long-term outsourcing arrangement have been identified and approved by the interviewees. They have been used to construct the 18C's model.

(c) 2012 Elsevier Inc. All rights reserved.
\end{abstract}

\section{Introduction}

In the search for organisational competitiveness, outsourcing has become a widespread management strategy. As a result, outsourcing has been and remains a popular subject for academic research, as can be seen in the reviews (Hätönen \& Eriksson, 2009; Kremic, Tukel, \& Rom, 2006), much of which have concentrated on the type of functions that should be outsourced (Hafeez, Malak, \& Zhang, 2007; Wu \& Park, 2009), how to select a service provider (Chen \& Chen, 2006; Lasch \& Janker, 2005; Rese, 2006; Tseng \& Lin, 2005), where to outsource (Bunyaratavej, Hahn, \& Doh, 2007, 2008; Doh, Bunyaratavej, \& Hahn, 2009; Graf \& Mudambi, 2005; Hätönen, 2009; Zaheer, Lamin, \& Subramani, 2009), and the benefits and risks associated with outsourcing (Di Gregorio, Musteen, \& Thomas, 2009; Harland, Knight, Lamming, \& Walker, 2005; Hoecht \& Trott, 2006a, 2006b; Jennings, 2002; Kremic et al., 2006). All these subjects are related to the initial stage of an outsourcing process.

As outsourcing has evolved in a more strategic way, cooperation, collaboration and co-development are required in order to achieve a mutual goal. Therefore, a close and long-term relationship is needed to achieve a sustainable competitive advantage (Franceschini, Galetto, Pignatelli, \& Varetto, 2003; Handley \& Benton, 2009; Helper \& Sako, 1995; Lee \& Kim, 1999; McHugh, Humphreys, \& Mclvor, 2003; Nistorescu \& Barbu, 2009). It has been recognised that management of an outsourcing relationship is essential to ensure long-term success, but often organisations lack the skills and expertise to do this (Harland et al., 2005; Power, Bonifazi, \& Desouza, 2004;

\footnotetext{
Submission dates: 13th April 2010, First revision: 16th December 2010, Second revision: 24th October 2011.

* Corresponding author. Tel.: + 442392844171.

E-mail addresses: Alessio.Ishizaka@port.ac.uk (A. Ishizaka), rebecca.blakiston@live.com (R. Blakiston).
}

Robinson et al., 2008; Spekman \& Caraway, 2006). For example, the Danish company Lego outsourced most of its manufacturing activity in 2006 to Flextronics and brought it back in house in 2008. The specificity of the machines prevented significant economies of scale from being achieved (Barthélemy, 2011). Coordination and control of the production were more complicated than in house, and was exacerbated by divergences and misalignments between the two companies (Larsen, Pedersen, \& Slepniov, 2010). After the terrorist attack of the 9/11/2001, Boeing decided to outsource most of its manufacturing activities to over 50 suppliers. In 2009, the 787 Dreamliner's production was two years behind schedule and Boeing decided to bring back in house their major production lines. The main reason was that Boeing lost control over its multiple suppliers (Barthélemy, 2011). The aim of this paper is to avoid outsourcing failures by building a robust framework to ensure a successful and sustainable long-term arrangement.

Outsourcing, when performed well, can result in the client organisation receiving benefits that they would have otherwise been unable to achieve by performing the activity in house. However, these benefits are not guaranteed, and there are furthermore large risks involved if an outsourcing arrangement is not successful. Therefore, it is important to determine the factors that contribute to ensuring a positive outcome and not only in the short term.

Previous research has used large questionnaires to tackle the issues amongst others, as to what or why to outsource (Claver, Gonzalez, Gasco, \& Llopis, 2002; Ellram, 1991; Elmuti, 2003; Kakabadse \& Kakabadse, 2002; Khong, 2005; Whipple \& Frankel, 2000). Later, a Delphi technique was used (Iacovou \& Nakatsu, 2008). Results were reported mainly on a quantitative format. Despite these studies, outsourcing still counts a high failure rate of one in four (Landis, Mishra, \& Porrello, 2005; Orbys Consulting, Henley Management College, \& Benchmark Research, 2006). Barthélemy (2003) recognised the inappropriateness of previous research methods and used face-to-face interviews to collect primary data from 
unsuccessful outsourcing arrangements. He found seven deadly sins in outsourcing. Our paper takes the same qualitative approach to elicit tacit distributed knowledge in order to investigate long-term successful outsourcing arrangements. In our study, eighteen key success factors are identified for an organisation to retain a good working relationship with its outsourcing service provider. As most of the previous researches were focussed on a single or only a few of these factors, there is the danger that the overall strategic intent of outsourcing would be lost. Our 18C's model ensures a holistic and sustainable management of the outsourcing process, which has not been previously described in the literature. After describing the research method and the company context, the newly developed model and its managerial implications will be discussed in detail.

\section{Research method}

In order to develop a model for a healthy long-term outsourcing relationship, several successful case studies of a company were used. The longitudinal multiple case study research allowed us to develop an understanding of this complex issue over several years and to expand upon or add strength to what is already known through previous research. In contrast to past research using large questionnaires (Claver et al., 2002; Ellram, 1991; Elmuti, 2003; Kakabadse \& Kakabadse, 2002; Khong, 2005; Whipple \& Frankel, 2000), this research will emphasise detailed contextual analysis. The information in this paper was obtained through interviews of key informants and through observations.

\subsection{Motivations of the selected research method}

Interviews provided the opportunity to speak directly to participants, which allowed the different views to be examined more closely and in greater depth than other methods would allow. Semistructured interviews are often used in qualitative in-depth research. According to Saunders, Lewis, and Thornhill (2009), they are advantageous in four situations:

- The purpose of the research is an explanatory study. In our case, we aim to infer a causal relationship between factors leading to a longterm relationship in outsourcing.

- Personal contact is important. It has been observed that participants prefer to be interviewed than to fill in a questionnaire (Saunders et al., 2009). They may be reluctant to spend time providing written explanatory answers and the researchers do not have control over who answers the questions. A face to face interview is an important tool to build trust in order to find out, in this study, the secrets of a long-term relationship in outsourcing.

- The nature of the question is complex. The order of the questions must be flexible depending on the flow of the conversation. Additional questions were required to elicit tacit knowledge.

- Completeness of the process is required. During interviews, participants tend to be generous with their time and are collaborative. Indeed, they provided us with many details of their experience.

It has been observed that trust and rapport are the most important factors contributing to a successful interview (Moyser \& Wagstaffe, 1985). As the second author has worked in the studied company for many years, access was facilitated to key people and relevant meetings.

\subsection{Design of the interviews}

The interviews were semi-structured, guided by pre-determined questions (Table 1). However, deviations from the agenda were made in order to explore new and particularly interesting points raised in the course of each interviews. The purpose of the interviews was to understand the nature of the relationship between the
Table 1

Interview structure.

Interview structure:

a) Interviewee

- What is your involvement in the outsourcing of facilities management?

b) Implementation

- What was the motivation behind the outsourcing of facilities management?

What decision process did you follow to implement the outsourcing of facilities management?

-Was the same decision and implementation process reused when outsourcing additional areas? If no, how and why did you change the process? What did you learn from the initial outsourcing process that caused you to change your approach?

c) Benefits in outsourcing

- What benefits have you experienced from outsourcing? Did they change over the duration of the arrangement? Did they meet your expectation?

d) Problems in outsourcing

- Have you experienced any problems as you progressed through the outsourcing arrangement? If yes, how did you overcome them?

- What have you learnt from the problems that you experienced?

e) Success factors

What factors do you think need to be taken into consideration to ensure a successful outsourcing arrangement?

- How do you measure the successfulness of an outsourcing arrangement?

Is there anything you would change in the current arrangements to ensure a more productive and effective relationship?

company and their service provider, the type of control system used in the outsourcing relationship, the problems encountered and how a long-term relationship has been achieved. Interviews lasted one hour each. The first person interviewed was the Facility Manager, in order to get his general view. This interview was also been used to validate the pertinence of the questions. As the collected data were relevant for our research, the interview structure was maintained for the next respondents. The last interview was scheduled one week later in order to be able to analyse previous interviews and detect any unanswered questions. As the last interviewee has the longest service in the company, he is the most experienced person to clarify uncertainties (Table 2). All interviews were tape recorded and transcribed. The six key persons interviewed were (in bold in Fig. 1):

\section{a) Client side}

- Facilities Manager (FM): He is in charge of all maintenance and repair outsourced departments in the company. He works in close relationship with the service provider in order to define the strategy.

- Engineering Manager (EM): He was hired in 2001 to manage the outsourcing process of the engineering departments, to monitor its progress and to manage the relationship with the service provider.

- Projects Team Leader (PTM): He is in charge of managing the outsourcing process of the project department, to monitor its progress and to manage the relationship with the service provider.

- Facilities Team Leader (FTM): He reports back the performances of the service provider to the Facility Manager, suggests improvements and implements the new strategy given by the Facility Manager.

- Procurement Manager (PM): He is in charge of managing the outsourcing process of the procurement department, to monitor its progress and to manage the relationship with the service provider.

Table 2

Interview schedule.

\begin{tabular}{lll}
\hline Date & Time & Interviewee \\
\hline 18/02/2009 & $13: 30$ & Facility Manager (FM) \\
03/03/2009 & $9: 00$ & Engineering Manager (EM) \\
03/03/2009 & $11: 00$ & Project Team Leader (PTL) \\
03/03/2009 & $13: 00$ & General Manager from service provider (GM) \\
03/03/2009 & $14: 00$ & Facility Team Leader (FTL) \\
$09 / 03 / 2009$ & $16: 00$ & Procurement Manager (PM) \\
\hline
\end{tabular}




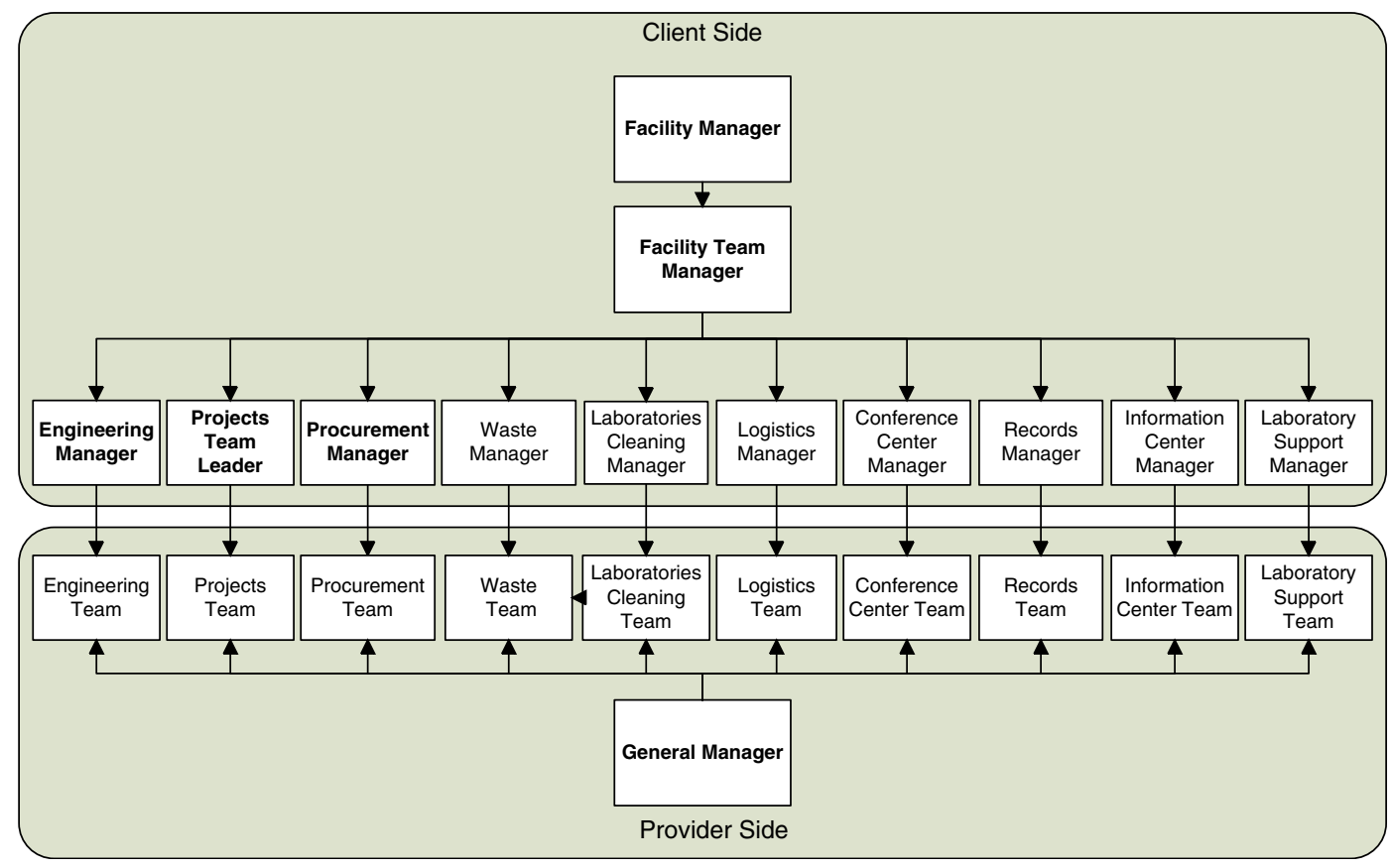

Fig. 1. Organisational structure of the outsourced area in facility management.

b) Service provider side

- General Manager (GM): He is in charge of "providing customer service, managing teams of people and providing strategic direction" (Interview GM).

In order to complement and confirm the interviews, the observation of four monthly performance review meetings was conducted. These observations gave an understanding of the real current interaction and relationship between the two organisations. Based on the interviews and observations, a model for a successful long-term partnership was constructed. Finally, in order to verify the correctness, the developed model was sent to the interviewees for comments and to the company for final approval.

\section{Company context}

The multi-national pharmaceutical company used in this study has progressively decided to outsource several facilities management (FM) activities since 2002. The relationship between the studied company and their respective service provider has been ongoing for over eight years. This section discusses the motivations and defines what a long-term successful arrangement is.

\subsection{Motivations for outsourcing}

The main motivation was to outsource all craft and technical level activities in order to concentrate on the core business (Interview EM). In a big exercise with consultants, core was defined as anything close, almost touching the product (Interview PM). Each department had already various parts of services delivered by external vendors (Interview FM). The next step was to regroup all these fragmented areas and outsource them to one organisation. As Facility Management is "a service that is regularly provided there is a good market place" (Interview EM). Part of the staff was transferred to the service provider but the management was retained in house and reinforced with a new Facility Team Leader position and some more experienced managers for the outsourced area. The immediate benefit was a simpler and thus easier relationship management: one contract, one representative (i.e. the General Manager of the service provider), one invoice and one process. The predicted economy of scale was rapidly achieved as "they have supplier lists, which they have negotiated good rates with" (Interview EM). Finally, the risk is transferred to the contractor: if "a supplier goes bankrupt, and they have to get another contractor on board, we don't pay for that" (Interview PTL).

\subsection{Long-term successful outsourcing}

Before identifying the factors that contribute to the success of an outsourcing arrangement, it is important to establish clarification between a successful and an unsuccessful outsourcing arrangement. There are firstly the quantifiable facts: far more detailed information has been available, which has improved cost management and budget planning. Overall facility management costs have dropped by $30 \%$ during the first three years and about $5 \%$ reduction every year (Interview PM). Problems are solved more quickly. Secondly, qualitative criteria are also important. The Facility Manager of the company explains that the measurement of a successful relationship is also: "partly down to gut feel. Are you getting the level of service and satisfaction from the relationship?" The answer is clearly yes, as the service provider recently won the "British Cleaning Council (BCC) Site Supervisor of the Year". The main criteria assessed for this award are innovation, staff management, training and client relationship. As in any other situations, if you like it, then you want more of it:

"With a successful outsourcing relationship you will be looking to extend and enhance... if you are looking at taking things back in house then it's probably unsuccessful" (Interview FM).

According to this distinction the arrangement between the company and their FM service provider is successful. They have seen a dramatic increase in the financial and operational scope that has been assigned to the service provider. The number of activities that the service provider is responsible for has risen from five in 2002 to sixteen in 2007. At the beginning, outsourced activities were only soft services, then incorporating maintenance and now also delivering projects. Consequently they have seen a corresponding increase in the service provider contract price of approximately 527\% over 
five years. The sixteen outsourced activities, which constitute our multiple outsourcing case study, are:

Since 2002

- Site Operations: Management and co-ordination of site activities.

- Catering services: Providing food and drink for site staff to purchase, and for conferences.

- Housekeeping: Office and site cleaning.

- Gardening: Maintenance of grounds.

- Security: Responsible for site security, to control entry and ensure company confidentiality is maintained.

Since 2004

- Engineering: Perform maintenance work across site.

- Waste management: Organisation of waste collection and disposal.

Since 2005

- Laboratories cleaning: Cleaning in laboratory areas.

- Logistics: Management of goods inwards, goods outwards and post distribution.

- Procurement: Contract supplier management.

\section{Since 2006}

- Conference Centre: Management of conference bookings and coordination of meeting room allocations.

- Green travel: Co-ordination of environmentally friendly travel plan e.g. provides shuttle-bus service.

- Projects: Management, co-ordination and delivery of infrastructure projects on site.

Since 2007

- Records Management: Categorisation and storage of business documentation.

- Information Centre: Knowledge information support including engineering planning and scheduling.

- Laboratory Support: Perform routine non-technical laboratory activities.

\section{The 18C's of the successful outsourcing model}

In our study, we identified 18 success factors that ensure a longterm outsourcing arrangement. We can split them into three types: (1) related to the client, (2) related to the service provider and (3) related to the interaction of both. These key findings have been used to construct a successful long-term model in outsourcing (Fig. 2).

\subsection{Success factors from the client side}

\subsubsection{Commitment from top management}

Top management set the overall tone and philosophy of the company. Therefore, they must be involved from the beginning and should be regularly informed of their service provider's performance. In our outsourcing case study, the headquarters' in the USA drove the decision to outsource the facilities services, through their strategy "to control headcount globally" (Interview EM). Once the decision to outsource had been made the local management team was responsible for the implementation. The first step was to "watch and observe" (Interview FM) what was happening at other organisations, particularly in other pharmaceutical companies. An outsourcing programme of 12 months was established at first with only soft services. Once the outsourcing process was fully operative, top managers of the client company began to receive a monthly update on performance and changes that are occurring. They also meet personally 3-4 times a year with the service provider's management team.

According to a recent Delphi survey, top management commitment is by far the most important success factor in outsourcing
(Iacovou \& Nakatsu, 2008). Top management support provides both encouragement and resources (e.g. human resources, time, travel, etc.). Without top management support and direction, the supplier would be unsure of its future and importance to the client (Ellram, 1991; Whipple \& Frankel, 2000). It is also unsettling for the individual employee's point of view as their situation is unclear: will they be transferred to the outsourcing vendor or even worse, be made redundant? Counterproductive anxiety arises and consequently they may begin to look for jobs elsewhere. Therefore, recommendations for the outsourcing process are unlikely to come from below. The senior management's lack of enthusiasm was one of the main reasons of the failure of the IT outsourcing by the Australian government because it did not motivate either the vendor or the employees (Seddon, 2001). In the USAA-IBM partnership, executive leadership was recognised as an important factor for a successful outsourcing arrangement (Donald, Blake, \& Srikka, 1991).

\subsubsection{Clear aims and objectives}

From the interviews conducted with client's and service's provider employees, it is apparent that the client organisation must have clear aims and objectives.

"The client should provide clarity, what is expected, their business objectives, customer service requirements, so that there is no ambiguity there" (Interview GM).

"You need to understand what your expectation is from outsourcing" (Interview FM).

Mazzawi (2002) claims that outsourcing can solve problems. This may be true for insufficient scale of economies or lack of expertise but not if problems are related to poor management (Barthélemy, 2003). The fundamental rule in outsourcing is "don't outsource a problem" (Interview FM \& PM). Many organisations outsource an area they are having difficulty managing, hoping that the service provider will be able to solve all of their problems because it is an expert in that business sector. However, a manager at the studied company has discovered that this is not the reality.

"If it is broken internally, if we outsource it would probably be twice, three times, ten times as bad" (Interview PM).

In fact with the outsourcing process, the direct control of activities is replaced by a control through a contract. The interviewed PM emphasised that problems should be fixed internally, as much as they can before the activity is outsourced. This trap was already observed in the outsourcing of library cataloguing (Dunkle, 1996) and IT and telecommunication as it is very difficult for a supplier to manage a customer's IT operations without detailed information about the current IT system (Hodosi \& Rusu, 2007; Honess, 1996). Often, companies believe that suppliers stay up to date with the latest technology. In fact, suppliers have the same decision process as any other client company: they upgrade when new technology is financially beneficial or when the customer demands it (Dunkle, 1996). Therefore, it is important to have a good understanding of the outsourced area in order to aim for the best service. It is recommended that client and service provider jointly develop written goal statements for their relationship (Quinn, 1999). Power et al. (2004) even recommend having a clear plan for the end of the relationship in order to minimise risks.

\subsubsection{Confidence}

A confidence in the "expertise, knowledge and capabilities" (Interview FTL) of the service provider leads the client organisation to "feel 


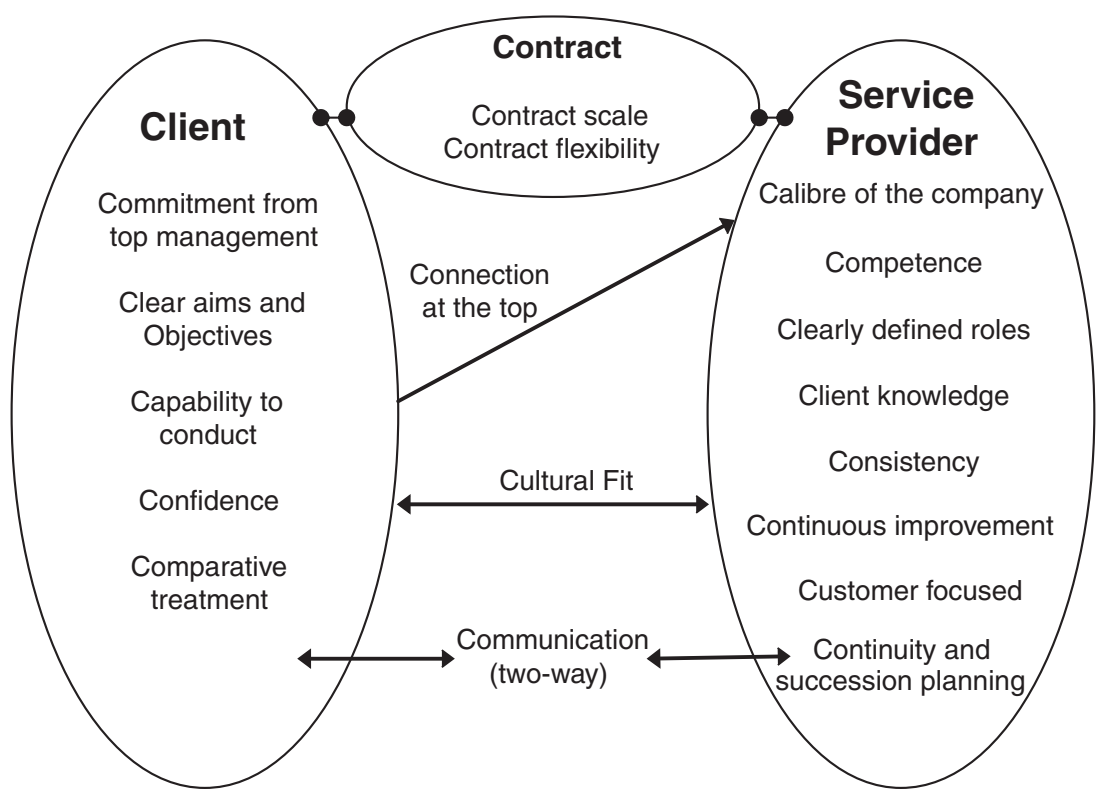

Fig. 2. The $18 C^{\prime}$ 's successful outsourcing model.

that actually it couldn't be done better ourselves" (Interview FTL and PM). Building confidence to this level has allowed the client company to value their service provider "as a partner rather than just a supplier" (Interview FTL). Subsequently, there needs to be a confidence that the client organisation could not provide a better service for a lower cost in house. This type of confidence encourages further collaboration (Claro, Claro, \& Hagelaar, 2006) and increases efficiency, as it eliminates the need for a management system to verify that the work has been done properly (Kirby, 2003). Several authors (Bullington \& Bullington, 2005; Fawcett, Magnan, \& Alvin, 2004; Ganesan, 1994; Handfield \& Bechtel, 2004; Hoecht \& Trott, 2006a; Nadin, 2008; Qureshi, Kumar, \& Kumar, 2007; Yilmaz, Sezen, \& Ozdemir, 2005) have stressed the importance of confidence (trust) in a supplier, particularly in a long-term relationship. Trust is one of the most commonly cited elements in buyer-supplier relationship, but it is also one of the most difficult factors to measure (Handfield \& Bechtel, 2004), it's hard to build and easy to destroy (Zhao \& Tamer Cavusgil, 2006).

\subsubsection{Comparative treatment}

Team working and ensuring a team atmosphere was identified by a number of interviewee's as a success factor for outsourcing. The studied company ensures a team atmosphere by mixing contractors with employees.

"Whoever is working together needs to sit together so they are seen as one team and don't have these artificial barriers" (Interview EM).

In addition, everyone working in the partnership should be treated equally regardless of their employer, i.e. whether they are an employee or a contractor.

"If you've got to a real true partnership approach you wouldn't differentiate, you wouldn't have double standards, so you wouldn't push a contractor any harder than you would push your own staff" (Interview GM).

In a game theory analysis, Bandyopadhyay and Pathak (2007) demonstrate that cooperation between employees of the client and service provider generates a higher pay-off. However, this is not feasible in every outsourcing situation as not all outsourcing arrangements involve using contractors as part of the day-to-day business activities. Often facility management contractors are clearly separated from the employees of the client organisation.

\subsubsection{Capability to conduct and control}

Management of the outsourcing arrangement must be "conducted in an ordered and disciplined way" (Interview FM). It is necessary to have the "right organisational structure internally" (Interview FM), this involves ensuring that you have the right people in house to be able to manage the outsourcing arrangement.

“People with clear expectations and understanding” (Interview FM).

The client organisation "would lead it and not have it imposed on them" (Interview FM).

Consequently, the studied organisation performed a restructuring exercise to enable them to ensure they had the right structure to be able to supervise the implementation and continued management of an outsourcing arrangement within their facility management function. This small management team must develop the strategy of the outsourced activities and keep it in alignment with the overall corporate strategy (Barthélemy, 2003). As it is a new role requiring different management skills, relationship managers may be hired (Lin, Pervan, \& McDermid, 2007; Useem \& Harder, 2000).

\subsection{Success factors from the service provider side}

\subsubsection{Calibre of the company}

Facility Management is a "people driven business" (Interview FM), therefore it is very important to have the right staff.

"The people involved need to know the site and what the site needs" (Interview PTL).

"The biggest challenge that we continue to have is having the right staff in place that understand our business and are able to support our business" (Interview FM).

"You need to select the right supplier" (Interview PM). 
By employing a service provider you should benefit from a high calibre company. It can attract high quality staff as they can "provide more career opportunities" (Interview PTL and EM) than the client organisation. The service provider also has the expertise to provide staff with training and qualifications, which the client organisation may not have the capacity or knowledge to deliver (Interview PTL). Companies increasingly understand that outsourcing for long-term intellectual value is much more profitable than outsourcing for short-term cost-cutting (Lewin \& Peeters, 2006; Lin \& Wu, 2010; Manning, 2008; Quinn, 1999).

\subsubsection{Consistency and clearly defined roles}

Consistency is also established as important to this outsourcing arrangement, as mentioned earlier the client organisation is concerned with people management.

The "company is very strongly based on relationship and interactions with people" (Interview FTM).

Therefore, it is important that roles and responsibilities are well defined. For example, the employees of the client organisation like the fact that 'Fred' delivers the post every day, if one day Fred delivered the post and the next he was driving the shuttle bus or cleaning, this "would dilute his capabilities and confuse the customer" (Interview FTM). Therefore, consistency in the people delivering the service and ensuring the role that they perform is clearly defined is important in this situation. Consistency is also fundamental to build trust (Oza, Hall, Rainer, \& Grey, 2006). Ackerman (1996) suspects that unclear roles are the most frequent cause for the collapse of outsourcing relationships.

\subsubsection{Continuous improvement}

Morgan (1989) noted that many firms believe that their future success will depend on a number of continuous improvement objectives, including: (1) 30 to $80 \%$ improvement in responding to customer needs; (2) 40 to $60 \%$ reduction in concept-to-market product cycle time; (3) 10 to $15 \%$ annual quality improvement; (4) $5 \%$ annual cost reduction. Today, continuous improvement also involves the outsourcing partners. They need to continuously improve "what they are bringing to us to demonstrate they are doing better than last year" (Interview EM). It is a clear expectation:

“We... expect continuous improvement" (Interview FTL).

To provide continuous improvement a service provider is required to give their staff appropriate training:

"We need to know...they want to develop their people" (Interview EM).

A scorecard has been introduced in order to measure the performance of the service provider (using a traffic light system). But, the dimensions "will never be all green because that would mean there is nothing more they can do better" (Interview EM). Increasingly, clients require a documented process for continuous improvement (Blumenberg, Wagner, \& Beimborn, 2009; Tate, Ellram, Bals, \& Hartmann, 2009) and some credentials like certifications (Wright, 2005) or past history (Persona, Regattieri, Pham, \& Battini, 2007; Rebernik \& Bradac, 2006). However, recognition should be given to a service provider for their outstanding performance in order to foster good relationships (Bullington \& Bullington, 2005). Finally continuous improvement is essential to allow the client organisation to remain confident in their service provider.

\subsubsection{Continuity and succession planning}

Continuity can be disrupted with unplanned external factors. For example in 2007, the service provider was sold and "the senior managers were focused on integrating with the new company, so our ability to get their attention and deal with the bigger issues was significantly limited" (Interview EM). From this case, the client learnt the importance to have "continuity and succession planning" (Interview FM and PM) in place. Unexpected challenges will happen in a long-term outsourcing arrangement. Therefore, human talent and not technology is essential (Kirby, 2003) to overcome such problems, subsequently issues can arise when good people leave (because of job change, promotion, injury, illness, death, job loss,...).

If business continuity is vague, inaccurate or even ignored, the organisation is open to potential exploitation by the service provider, which puts the reputation of the client at risk (Walker, 2006). A close customer-supplier relationship is needed to smooth out the effect of these unplanned changes and maximise the benefits of the planned improvements (Bullington \& Bullington, 2005). Business continuity risks is a reason sometimes evocated to renounce in outsourcing (Ellram, Tate, \& Billington, 2008).

\subsubsection{Customer focussed}

The service provider must be "focused on trying to satisfy what the customer needs" (Interview EM). After all, the basic reason for outsourcing is to acquire value from the service provider. Webb and Laborde (2005) believe that it is the unwritten contract between the service provider and the client, and their effort "to go an extra mile", that strengthens the relationship. Even if a scorecard has been implemented to measure performance, excellence of customer focus is difficult to measure and is often based on a subjective feeling. What happens if opinions are conflicting? The EM responds: "We are the customer, it's our scorecard, and if there is disagreement we have the final say". As it has been observed (Kannan \& Tan, 2006), supplier performance is positively correlated with relationship health, it can be deduced that they belong to a nurturing cycle. If the performance is high, then the relationship will be healthier, which will imply a higher performance and so on.

\subsubsection{Client knowledge}

In order to be customer focussed a service provider is required to know their client perfectly.

"Right staff in place that understand our business" (Interview FM).

This encompasses not only the knowledge of the site (Interview EM and PTL) but also the core values and beliefs of the client (Interview GM). Successful relationships depend on Key Performance Indicators (KPIs) that reflect the top priorities of the firm. The process of discussing the customer's needs, allocating degrees of importance, setting targets and using performance based payment is a motivator and a key success factor (Burdon \& Bhalla, 2005). However benefits should be competitive or better than the other clients in order to incentivise further the motivation. If there is no congruence between the goals of the client and the supplier or the expectations are not realistically established, a conflict between the companies is likely to occur (Gibler \& Black, 2004; Mentzer, Min, \& Zacharia, 2000).

\subsubsection{Competence}

One of the reasons for outsourcing is the potential for improvements in service and access to expertise.

"You need to find the right organisation...that can do the job, so that's their core business" (Interview EM).

"We benefit from an ability to have an FM provider, that's what they specialise in, that's their core business" (Interview FTL). 
The client organisation has decided to outsource non-core activities (like facility management), which allows them to take advantage of their service provider's supply chains, expertise and to concentrate their efforts on their core activities. Therefore, the outsourced activities must be the core business of the supplier (Hafeez et al., 2007).

Choosing a wrong vendor has been qualified as a deadly sin by Barthélemy (2003). He underlines that a proficiency and trustworthiness should be carefully assessed. A performance evaluation could be done directly by first proposing small deals to a large number of suppliers in order to make a personal evaluation and then select the most suitable. An indirect evaluation is also possible, for example in inquiring with existing clients of the prospective supplier.

\subsection{Success factors from the interaction client-service provider}

\subsubsection{Communication}

Communication is regarded by the managers of the client organisation as a very important factor for consideration, regardless of the activities involved. They believe that "all issues are down to poor communication" (Interview FTL) and to ensure success you need to have the right communication. This involves communicating with the right person at the right level. The level of communication could vary for different customers or stakeholders.

Communication was emphasised by another interviewee; it is important that the service provider listens and is reactive.

"When we are not happy we talk about it" (Interview PTL).

The service provider's management was of the same opinion. For best practice and maximum performance they suggest that the client organisation and the service provider need to be aligned and for this to happen then they "need to allow them access to all information" (Interview GM)

Communication is obviously fundamental to ensuring success, however both points above regarding communication are concerned with the client organisation providing information or facilitating communication with their service provider. The other way is also true. By outsourcing, the client is losing a measure of control over the functions. If the service provider does not communicate proactively, this sudden loss of control can cause great stress and anxiety, which can hinder a healthy relationship (Webb \& Laborde, 2005).

Through observation of a monthly performance review meetings, the observer became aware of an issue that had arisen regarding reduction in VAT rates. A subcontracting company was not passing on reductions in the VAT rates to customers in the cafeteria and coffee areas, arguably to counter increasing food prices. This had not been communicated to either the service provider or the client organisation and was only noticed when a customer made a complaint. It was felt in the meeting that this was unacceptable and that communication lines needed emphasising. This seems a small issue but only good and systematic communication can lead to a healthy client-supplier relationship (Bullington \& Bullington, 2005; Langfield \& Greenwood, 1998).

Conversely though, another interviewee put forward that "over communication is as bad as no communication" (Interview FTL). He emphasises this point by stating that it takes time to communicate and "time is money". Communication involves people's time and this time is consequently not spent delivering service to the business. Furthermore, over-communication leads to an "awful lot of data floating around the business" (Interview FTL). It can be assumed that quality of the communication is more important than quantity (Wastli \& Wastli, 2006).

Evidently, the correct level of communication is imperative in an outsourcing arrangement. Merely emphasising the importance of communication is not sufficient, as this could result in over communication, which, as mentioned above, costs the client organisation money and consequently diminishes the cost savings of outsourcing.
Therefore, it may be necessary to stress levels of communication that are appropriate in different circumstances.

\subsubsection{Contract scale and connection to the top}

One element that is often overlooked when selecting a service provider is the contract size scale. According to the studied company, when selecting a service provider you should preferably be one of their top ten customers.

By being one of the top ten customers of their service provider, the studied company is able "to see the senior people" (Interview EM) from the service provider organisation. If they were the 80th or 90th customer then the service provider's top management would not prioritise the time to see them.

"So it is all about getting the right scale...you don't want to be too small... but you don't want to be too big either" (Interview EM).

A large contract gives leverage:

"We are spending $£ 1$ million with you and you are still not delivering correctly on this site" (Interview PTL).

However it is important to get the size right, be one of the top ten customers but small enough so they can survive without your business, "so they are not dependent" (Interview EM). While it would seem to be to the buyer's advantage to lock-in its supplier partner, the benefits are likely to be short lived, with the temptation of the powerful client to abuse their situation, so a healthy buyer-supplier relationship is impossible. Excessive pressure may throw the service provider in a state of chaos and confusion that negatively affects management processes and functions. The trapped and paralyzed service provider, unable to satisfy the demand of the client, is likely to receive more pressure and enter in a vicious spiral of negativity (McHugh et al., 2003). This negative phenomenon has also been observed in a power asymmetry situation in favour of the service provider (Fawcett et al., 2004). For example in the car industry, the car makers often use their power over the dealers, which leads to a tense relationship (Nadin, 2008).

The studied company utilise their connection at the top by meeting with the service provider's senior management three or four times a year. This allows the studied company to give feedback directly to the top management of their service provider and regularly discuss changes to the arrangement, including improvements that can be made.

The success factors identified in this section are consideration of the contract scale and consequential connection at the top of the service provider's organisation. The involvement of top management is often identified as a success factor for outsourcing (see section commitment from the top management above), however this referred to the involvement of top management within the client organisation, whereas this research has emphasised that it is also important to gain the recognition and support from the service provider's top management.

\subsubsection{Contract flexibility}

In the long term, the benefits of an outsourcing agreement can decrease if the contract does not provide flexibility and room for growth. As businesses evolve, demands are likely to change. For example, new cheaper or superior technologies become available, but an organisation may find itself unable to take advantage of them because its outsourcing contract does not permit such accessibility.

"If we had tried to produce a contractual agreement that was fixed price then that would have been counter to what we are trying to achieve" (Interview EM).

"When we are not happy we talk about it. It is not a fixed price contract therefore we have a lot of control" (Interview PLT). 
The contractual arrangement is set "to support what you are trying to achieve rather than achieving a purchasing goal of minimising cost and transferring risk" (Interview EM). This statement supports the surveys (Dickson, 1966; Weber, Current, \& Benton, 1991) concluding that, quality is the main reason for outsourcing and not cost. Hau Lee has observed that successful relationships are characterised by those companies who manage transitions (changing market conditions, evolving technology, different customer requirements, etc.) well, rather than focussing on cost, flexibility and speed (Kirby, 2003). The contract needs to change over time to facilitate and allow for continuous improvement (see section continuous improvement). Finally, it is the client's responsibility to identify the required changes because it is inappropriate for a supplier to specify the requirements of an outsourcing arrangement and fulfil them (Reid-Thomas \& Phillips, 2005):

"Once you decided on a measurement and have improved it, pick something else and improve that. That is why it is dangerous to write a contract unless you are prepared to change the contract" (Interview EM).

\subsubsection{Cultural fit}

Five of the six people interviewed in this research study mentioned cultural fit, so it can be assumed that this is an important factor in the outsourcing arrangement.

"The cultural fit has got to be right, the right fit, but that doesn't mean it's got to be the same because there are aspects of our culture and behaviour that we want to and need to change" (Interview FTL).

It is suggested that, not everything the client organisation does or requests is right or best practice. Ultimately, the primary goal of outsourcing is to improve efficiencies, to learn new strategies and to run the business in a better way. The service provider is the expert in the field; therefore it may be appropriate for the service provider to have a different culture to facilitate service delivery, especially at an operational level. However at a high level, the two organisations must culturally match:

"The values of both organisations have got to be aligned" (Interview FTL).

"At a high level the two organisations culturally match" (Interview EM).

Culture is very difficult to identify, assess and measure.

"When selecting a supplier we try to pick the best match that we can" (Interview FPM).

It could take considerable time and effort to gain a comprehensive understanding of a potential service provider's culture. The studied company suggests that a measure of culture can be achieved by:

"Visits to the supplier, asking lots of questions, meeting their management, hearing their spout on visions and values, and assessing their track record" (Interview PM).

Cultural fit is arguably more important than communication because even if the contractor understands the objectives and strategies of the client, it may disagree with him. Service providers may believe that their superior specialized knowledge gives them the right and responsibility to provide what they think is the best for their client despite the received directives (Gibler \& Black, 2004).

\section{Conclusion}

A long-term relationship between client and supplier creates an atmosphere of trust and commitment, which promotes performance. However long-term arrangements are difficult to implement and maintain. Through a detailed qualitative contextual analysis, supported by a literature review, we have identified simultaneously, for the first time, 18 key success factors leading to the 18C's outsourcing model. An important message of this article is that every company needs to give serious and continuous attention to outsourcing arrangements. The developed $18 \mathrm{C}$ 's outsourcing model has substantial managerial implications (links with the 18C's factors below in italic). Some outsourcing processes are doomed to fail even before the relationship has actually started. When the client company does not have clear aims and objectives, selects an unsuitable (incompetent or culturally dissimilar) or low calibre service provider, and writes a poor or inflexible contract, they cannot expect a long-term relationship.

The implementation of the $18 \mathrm{C}$ 's outsourcing model is time consuming, costly and requires changes in the organisation. The studied company has set up a department to conduct, control, learn and capitalise expertise from each outsourcing experience. These in house talents have been more valuable than outside consultants, because they understand better the company's specific needs. Even when the outsourcing activities are fully operational and boundaries have dissolved, permanent teams working on both sides are needed to maintain and fortify the relationship. As the company becomes increasingly virtual, expertise about outsourcing and service provider management will be more and more crucial. Personal contacts and open communication must be established between both companies at three levels:

a)Top managers' commitment and connection on both sides are permanently needed. It gives confidence to all stakeholders. Its participation motivates the middle managers, fosters innovation, encourages (often financially) the adoption of new technologies and ensures responsiveness if a lower level bottleneck arises. They are also responsible for preparing a continuity and succession plan for unforeseen events, which will necessarily happen in a long-term arrangement. b)Champions on both sides, whose performance evaluation is directly correlated to the success of the relationship client-supplier. One important task of the client's champion is to implement a comparative treatment to internal and external staff. The service provider's champion should ensure a consistent, customer focussed and continuously improving service. His organisation must always demonstrate competence and knowledge of the client in order to keep the confidence of the customer.

c)Several operational managers with clearly defined roles on both sides who develop personal relationships in order to solve day to day problems.

However, some companies see outsourcing as a cost cutter and do not invest, or only superficially invest, in setting a well managed relationship with their service provider as described in this paper (McIvor \& McHugh, 2000; Sanders, Locke, \& Autry, 2007). This negligence may explain the high failure rate that still exists in outsourcing, one in four according to Landis et al. (2005) and Orbys Consulting et al. (2006).

\section{Acknowledgements}

The authors are indebted to their colleagues Andreas Hoecht and Ian Stevens, and two anonymous referees for their valuable 
comments and suggestions, which have greatly improved the earlier version of the paper.

\section{References}

Ackerman, K. (1996). Pitfalls in logistics partnerships. International Journal of Physical Distribution and Logistics Management, 26(3), 35-37.

Bandyopadhyay, S., \& Pathak, P. (2007). Knowledge sharing and cooperation in outsourcing projects - A game theoretic analysis. Decision Support Systems, 43(2), 349-358.

Barthélemy, J. (2003). The seven deadly sins of outsourcing. The Academy of Management Executive, 17(2), 87-100.

Barthélemy, J. (2011). The Disney-Pixar relationship dynamics: Lessons for outsourcing vs. vertical integration. Organizational Dynamics, 40(1), 43-48.

Blumenberg, S., Wagner, H. -T., \& Beimborn, D. (2009). Knowledge transfer processes in IT outsourcing relationships and their impact on shared knowledge and outsourcing performance. International Journal of Information Management, 29(5), 342-352.

Bullington, K., \& Bullington, S. (2005). Stronger supply chain relationships: Learning from research on strong families. Supply Chain Management: An International Journal, 10(3), 192-197.

Bunyaratavej, K., Hahn, E., \& Doh, J. (2007). International offshoring of services: A parity study. Journal of International Management, 13(1), 7-21.

Bunyaratavej, K., Hahn, E., \& Doh, J. (2008). Multinational investment and host country development: Location efficiencies for services offshoring. Journal of World Business, 43(2), 227-242.

Burdon, S., \& Bhalla, A. (2005). Lessons from the untold success story: outsourcing engineering and facilities management. European Management Journal, 23(5), $576-582$.

Chen, K. S., \& Chen, K. L. (2006). Supplier selection by testing the process incapability index. International Journal of Production Research, 44(3), 589-600.

Claro, D., Claro, P., \& Hagelaar, G. (2006). Coordinating collaborative joint efforts with suppliers: the effects of trust, transaction specific investment and information network in the Dutch flower industry. Supply Chain Management: An International Journal, 11(3), 216-224.

Claver, E., Gonzalez, R., Gasco, J., \& Llopis, J. (2002). Information systems outsourcing reasons, reservations and success factors. Logistics Information Management 15(4), 294-308.

Di Gregorio, D., Musteen, M., \& Thomas, D. (2009). Offshore outsourcing as a source of international competitiveness for SMEs. Journal of International Business Studies, 40(6), 969-988

Dickson, G. W. (1966). An analysis of vendor selection: Systems and decision. Journal of Purchasing, 1(2), 5-17.

Doh, J., Bunyaratavej, K., \& Hahn, E. (2009). Separable but not equal: The location determinants of discrete services offshoring activities. Journal of Internationa Business Studies, 40(6), 926-943.

Donald, L., Blake, I., \& Srikka, J. (1991). USAA-IBM partnerships in information technology: Managing the image project. MIS Quarterly, 15(4), 551-565.

Dunkle, C. (1996). Outsourcing the catalog department: A meditation inspired by the business and library literature. The Journal of Academic Librarianship, 22(1), 33-44.

Ellram, L. (1991). Key success factors and barriers in international purchasing partnerships. Management Decision, 29(7), 38-44.

Ellram, L., Tate, W., \& Billington, C. (2008). Offshore outsourcing of professiona services: A transaction cost economics perspective. Journal of Operations Management 26(2), 148-163.

Elmuti, D. (2003). The perceived impact of outsourcing on organizational performance. American Journal of Business, 18(2), 33-41.

Fawcett, S., Magnan, G., \& Alvin, W. (2004). Supply chain trust is within your grasp. Supply Chain Management Review, 8(2), 20-26.

Franceschini, F., Galetto, M., Pignatelli, A., \& Varetto, M. (2003). Outsourcing: Guidelines for a structured approach. Benchmarking an International Journal, 10(3), 246-260.

Ganesan, S. (1994). Determinants of long-term orientation in buyer-seller relationships Journal of Marketing, 58(2), 1-19.

Gibler, K., \& Black, R. (2004). Agency risks in outsourcing corporate real estate functions. Journal of Real Estate Research, 26(2), 137-160.

Graf, M., \& Mudambi, S. (2005). The outsourcing of IT-enabled business processes: A conceptual model of the location decision. Journal of International Management, 11(2), 253-268

Hafeez, K., Malak, N., \& Zhang, Y. (2007). Outsourcing non-core assets and competences of a firm using analytic hierarchy process. Computers and Operations Research, 34(12), 3592-3608

Handfield, R., \& Bechtel, C. (2004). Trust, power, dependence, and economics: Can SCM research borrow paradigms? International Journal of Integrated Supply Management $1(1), 3-32$.

Handley, S., \& Benton, W. C., Jr. (2009). Unlocking the business outsourcing process model. Journal of Operations Management, 27(5), 344-361.

Harland, C., Knight, L., Lamming, R., \& Walker, H. (2005). Outsourcing: assessing the risks and benefits for organisations, sectors and nations. International Journal of Operations \& Production Management, 25(9), 831-850.

Hätönen, J. (2009). Making the locational choice: A case approach to the development of a theory of offshore outsourcing and internationalization. Journal of International Management, 15(1), 61-76.

Hätönen, J., \& Eriksson, T. (2009). $30+$ years of research and practice of outsourcing Exploring the past and anticipating the future. Journal of International Management 15(2), 142-155.
Helper, S., \& Sako, M. (1995). Supplier relations in Japan and the United States: Are they converging? Sloan Management Review, 36(3), 77-84.

Hodosi, G., \& Rusu, L. (2007). A software tool that supports decisons for companies to outsource information technology or not. Paper presented at the MCIS 2007 Proceedings, Venice.

Hoecht, A., \& Trott, P. (2006). Innovation risks of strategic outsourcing. Technovation, 26(5-6), 672-681.

Hoecht, A., \& Trott, P. (2006). Outsourcing, information leakage and the risk of losing technology based competencies. European Business Review, 18(5), 395-412.

Honess, S. (1996). Outsourcing - A legal perspective on contract critical success factors. Information Security Technical Report, 1(3), 57-58.

Iacovou, C., \& Nakatsu, R. (2008). A risk profile of offshore-outsourced development projects. Communications of the ACM, 51(6), 89-94.

Jennings, D. (2002). Strategic sourcing: benefits, problems and a contextual model. Management Decision, 40(1), 26-34.

Kakabadse, A., \& Kakabadse, N. (2002). Trends in outsourcing: contrasting USA and Europe. European Management Journal, 20(2), 189-198.

Kannan, V., \& Tan, K. (2006). Buyer-supplier relationships: The impact of supplier selection and buyer-supplier engagement on relationship and firm performance. International Journal of Physical Distribution and Logistics Management, 36(10), 755-775.

Khong, K. (2005). The perceived impact of successful outsourcing on customer service management. Supply Chain Management: An International Journal, 10(5), 402-411.

Kirby, J. E. (2003). Supply chain challenges: Building relationships - A conversation with Scott Beth, David N. Burt, William Copacino, Chris Gopal, Hau L. Lee, Robert Porter Lynch, and Sandra Morris. Harvard Business Review, 81(7), 64-73.

Kremic, T., Tukel, O., \& Rom, W. (2006). Outsourcing decision support: A survey of benefits, risks, and decision factors. Supply Chain Management: An International Journal, 11(6), 467-482.

Landis, K., Mishra, S., \& Porrello, K. (2005). Calling a change in the outsourcing market: The realities for the world's largest organisations. Deloitte Consulting Report.

Langfield, S., \& Greenwood, M. (1998). Developing co-operative buyer-supplier relationships: A case study of Toyota. Journal of Management Studies, 35(3), 331-351

Larsen, M., Pedersen, T., \& Slepniov, D. (2010). Lego group: An outsourcing journey. Ecch the case for learning, 9B10M094 (pp. 1-16).

Lasch, R., \& Janker, C. (2005). Supplier selection and controlling using multivariate analysis. International Journal of Physical Distribution and Logistics Management, 35(6), 409-425.

Lee, J. -N., \& Kim, Y. -G. (1999). Effect of partnership quality on IS outsourcing success: Conceptual framework and empirical validation. Journal of Management Information Systems, 15(4), 29-61.

Lewin, A., \& Peeters, C. (2006). The top-line allure of offshoring. Harvard Business Review, 84, 22-24.

Lin, C., Pervan, G., \& McDermid, D. (2007). Issues and recommendations in evaluating and managing the benefits of public sector IS/IT outsourcing. Information Technology Es People, 20(2), 161-183.

Lin, B. -W., \& Wu, C. -H. (2010). How does knowledge depth moderate the performance of internal and external knowledge sourcing strategies? Technovation, 30(11-12), $582-589$.

Manning, S. (2008). A dynamic perspective on next-generation offshoring: The global sourcing of science and engineering talent. Academy of Management Perspectives, 22(3), 35-54.

Mazzawi, E. (2002). Transformational outsourcing. Business Strategy Review, 13(3), 39-43.

McHugh, M., Humphreys, P., \& McIvor, R. (2003). Buyer-supplier relationships and organizational health. Journal of Supply Chain Management, 39(2), 15-25.

Mclvor, R., \& McHugh, M. (2000). Collaborative buyer supplier relations: Implications for organization change management. Strategic Change, 9(4), 221-236.

Mentzer, J., Min, S., \& Zacharia, Z. (2000). The nature of interfirm partnering in supply chain management. Journal of Retailing, 76(4), 549-568.

Morgan, J. (1989). Are you tough enough for the 1990s? Purchasing, 104(7), 50-51.

Moyser, G., \& Wagstaffe, M. (1985). The methodology of elite interviewing. London: ESRC Grant report H00250003.

Nadin, G. (2008). Dealer-carmaker relationship: the theories of the duality of trust and of power-dependence. International Journal of Automotive Technology and Management, $8(1), 71-89$.

Nistorescu, T., \& Barbu, C. (2009). Outsourcing: long-term competitive strategy. Metalurgia International, 14 (6 special issue), 22-26.

Orbys Consulting, Henley Management College, \& Benchmark Research (2006). One in four outsourcing contracts are being taken back in house. Retrieved 10th January 2010, from. http://www.orbys.com/admin/files/retailbulletin_27.04.06.pdf.

Oza, N., Hall, T., Rainer, A., \& Grey, S. (2006). Trust in software outsourcing relationships: An empirical investigation of Indian software companies. Information and Software Technology, 48(5), 345-354

Persona, A., Regattieri, A., Pham, H., \& Battini, D. (2007). Remote control and maintenance outsourcing networks and its applications in supply chain management. Journal of Operations Management, 25(6), 1275-1291.

Power, M., Bonifazi, C., \& Desouza, K. (2004). The ten outsourcing traps to avoid. Journal of Business Strategy, 25(2), 37-42.

Quinn, J. (1999). Strategic outsourcing: Leveraging knowledge capabilities. MIT Sloan Management Review, 40(4), 9-21.

Qureshi, M., Kumar, D., \& Kumar, P. (2007). Modelling the logistics outsourcing relationship variables to enhance shippers' productivity and competitiveness in logistical supply chain. International Journal of Productivity and Performance Management, 56(8), 689-714. 
Rebernik, M., \& Bradac, B. (2006). Cooperation and opportunistic behaviour in transformational outsourcing. Kybernetes, 35(7/8), 1005-1013.

Reid-Thomas, D., \& Phillips, R. (2005). Facilities management outsourcing in the UK: Avoiding "elephant traps" in the legal jungle. Journal of Facilities Management, 3(3), 254-272.

Rese, M. (2006). Successful and sustainable business partnerships: How to select the right partners? Industrial Marketing Management, 35(1), 72-82.

Robinson, J., Lowes, P., Loughran, C., Moller, P., Shields, G., \& Klein, E. (2008). Why settle for less? Deloitte Consulting Report.

Sanders, N., Locke, A., \& Autry, C. (2007). A multidimensional framework for understanding outsourcing arrangements. Journal of Supply Chain Management, 43(4), 3-15.

Saunders, M., Lewis, P., \& Thornhill, A. (2009). Research methods for business students. Harlow: Pearson.

Seddon, P. (2001). The Australian federal government's clustered-agency IT outsourcing experiment Communications of the Association for Information Systems, 5(13), 1-33.

Spekman, R., \& Caraway, R. (2006). Making the transition to collaborative buyer-supplier relationships: An emerging framework. Industrial Marketing Management, 35(1), 10-19.

Tate, W., Ellram, L., Bals, L., \& Hartmann, E. (2009). Offshore outsourcing of services: An evolutionary perspective. International Journal of Production Economics, 120(2), 512-524.

Tseng, Y. J., \& Lin, Y. H. (2005). A model for supplier selection and tasks assignment. Journal of American Academy of Business, 6(2), 197-207.

Useem, M., \& Harder, J. (2000). Leading laterally in company outsourcing. Sloan Management Review, 41(2), 25-36.

Walker, A. (2006). Business continuity and outsourcing - Moves to take out the risk. Network Security, 2006(5), 15-17.

Wastli, S., \& Wastli, S. (2006). Trust in buyer-supplier relations: The case of the Turkish automotive industry. Journal of International Business Studies, 39(1), 118-131.

Webb, L., \& Laborde, J. (2005). Crafting a successful outsourcing vendor/client relationship. Business Process Management, 11(5), 437-443.

Weber, C. A., Current, J. R., \& Benton, W. C. (1991). Vendor selection criteria and methods. European Journal of Operational Research, 50(2), 2-18.

Whipple, J., \& Frankel, R. (2000). Strategic alliance success factors. Journal of Supply Chain Management, 36(3), 21-28.
Wright, T. (2005). Outsourcing - Financial Services Authority report on offshoring Computer Law \& Security Report, 21(6), 500-504.

Wu, L., \& Park, D. (2009). Dynamic outsourcing through process modularization. Business Process Management, 15(2), 225-244.

Yilmaz, C., Sezen, B., \& Ozdemir, O. (2005). Joint and interactive effects of trust and (inter) dependence on relational behaviors in long-term channel dyads. Industrial Marketing Management, 34(3), 235-248.

Zaheer, S., Lamin, A., \& Subramani, M. (2009). Cluster capabilities or ethnic ties? Location choice by foreign and domestic entrants in the services offshoring industry in India. Journal of International Business Studies, 40(6), 944-968.

Zhao, Y., \& Tamer Cavusgil, S. (2006). The effect of supplier's market orientation on manufacturer's trust. Industrial Marketing Management, 35(4), 405-414.

Alessio Ishizaka is Senior Lecturer at the Portsmouth Business School of the University of Portsmouth since 2007. He received his PhD from the University of Basel (Switzerland). He worked successively for the University of Exeter (UK), University of York (UK) and Audencia Grande Ecole de Management Nantes (France). He has been visiting professor at the Université d'Aix-Marseille, Università degli Studi di Torino, Università degli Studi della Tuscia and Università degli Studi di Padova. His research is in the area of decision-making and supply chain management, where he has published more than 30 papers. He was the co-organiser and keynote speaker of several conferences in these topics. He is a founding member of the Decision Deck Association (http://www.decision-deck.org/).

Rebecca Blakiston is a Business Studies graduate from Portsmouth Business School of the University of Portsmouth. During her four-year degree course she undertook year's work placement at the case study company, which enabled this research to be conducted. Following her graduation she returned to working for the company as a Financial Analyst before joining Trader Media Group. 